JERZY GOCKO SDB

Katedra Teologii Moralnej Społecznej KUL

e-mail:Jerzy@Gocko.pl

DOI: http://dx.do.org/10.18290/rt.2019.66.3-15

\title{
KRONIKA INSTYTUTU TEOLOGII MORALNEJ KUL ZA ROK AKADEMICKI 2017/2018
}

\section{STUDENCI}

W nowym roku akademickim studia doktoranckie w Instytucie Teologii Moralnej rozpoczęli: ks. Pavel Aliaskevich, ks. Grzegorz Basara i Artur Łyczak.

\section{PRACE DYPLOMOWE}

\section{A. Prace doktorskie}

W Instytucie Teologii Moralnej pod kierunkiem samodzielnych pracowników naukowych sfinalizowano cztery przewody doktorskie:

Samuel S a k a b a na wniosek Komisji Rady Wydziału KUL z dnia 26 czerwca 2018 r. uzyskał doktorat z teologii moralnej na podstawie rozprawy pt. Moral Implications of Divine Mercy in Individual, Ecclesial and Social Life of Nigerians. Lublin 2018 ss. 284. Publiczna obrona odbyła się 20 czerwca 2018 r. Promotorem rozprawy był ks. dr hab. S. Nowosad, prof. KUL, a recenzentami ks. dr hab. Andrzej Pryba, prof. UAM i ks. dr hab. Bartosz Adamczewski, prof. UKSW.

Alena A n d r o s i k na wniosek Komisji Rady Wydziału KUL z dnia KUL z dnia 26 czerwca 2018 r. uzyskała doktorat z teologii moralnej na podstawie rozprawy pt. Wiara w Boga jako fundament chrześcijańskiego życia moralnego wedtug ks. Leona Haroszki MIC (1911-1977). Lublin 2018 ss. 163. Publiczna obrona odbyła się 21 czerwca 2018 r. Promotorem rozprawy był ks. dr hab. S. Nowosad, prof. KUL, a recenzentami ks. dr hab. Piotr Kieniewicz i ks. dr hab. Zbigniew Wanat (UMK Toruń).

Ks. Jakub K a p e 1 a k na wniosek Komisji Rady Wydziału KUL z dnia 26 czerwca 2018 r. uzyskał doktorat $\mathrm{z}$ teologii moralnej na podstawie rozprawy pt. Troska 
o zdrowie $i$ życie człowieka $w$ sytuacjach granicznych. Studium teologicznomoralne. Lublin 2018 ss. 297. Publiczna obrona odbyła się 19 czerwca 2018 r. Promotorem rozprawy był ks. bp dr hab. Józef Wróbel SCJ, prof. KUL, a recenzentami ks. dr hab. Andrzej Muszala, prof. UPJPII i ks. dr hab. Maciej Olczyk, prof. UAM.

Magdalena $Ł$ o ń s k a na wniosek Komisji Rady Wydziału KUL z dnia 27 września 2018 r. uzyskała doktorat z teologii moralnej na podstawie rozprawy pt. Podstawowe założenia biopolityki w świetle nauczania Kościoła. Studium teologicznomoralne. Lublin 2018 ss. 258. Publiczna obrona odbyła się 24 września 2018 r. Promotorem rozprawy był ks. prof. dr hab. Jerzy Gocko, a recenzentami ks. dr hab. Wiesław Łużyński (UMK Toruń) i ks. dr hab. Mariusz Chamarczuk (Wyższa Szkoła Kadr Menedżerskich w Koninie).

\section{B. Prace magisterskie}

Pod kierunkiem o. prof. dr. hab. Andrzeja Derdziuka:

Marcin G a 1 a n t y: Postawa małżeństwa Chiary i Enrico Petrillo wobec cierpienia.

Paweł G a w r o ń s k i: Moralne aspekty dopalaczy.

Borys K a r c z m a r z y k: Przekaz wartości w twórczości ikonograficznej Marcina 'Fugitivusa' Świądra OFMCap.

Sebastian P i a s e k: Wiara jako rozumna odpowiedź człowieka na poszukiwanie sensu życia w świetle przemówień papieża Benedykta XVI podczas pielgrzymek do Niemiec.

Janis S a v i c k i s: Wiara religijna w ujęciu Jānisa Andrejsa Pavlovskisa OFMCap (1914-2000).

Pod kierunkiem ks. prof. dr. hab. Jerzego Gocki:

Elżbieta F i 1 i p i a k: Teologicznomoralne i społeczno-prawne aspekty świętowania niedzieli.

Konrad R o s z c z y k SDB: Zaburzenia odżywiania i ich przezwyciężanie w kontekście ideologii healthismu.

Łukasz T o r b i c k i SDB: Koncepcja lidera charyzmatycznego na przykładzie życia i działalności św. Jana Bosko.

Pod kierunkiem ks. dr. hab. Sławomira Nowosada, prof. KUL:

Mykola K a m i n s k y i: Sumienie i jego chrześcijańska formacja w ujęciu wybranych filozofów rosyjskich srebrnego wieku.

Marcin K o r n a g a: Moralny wymiar naśladowania Chrystusa w ujęciu Dietricha Bonhoeffera.

Raman V a i t s e k h o v i s h: Rodzina chrześcijańska w świetle listów pasterskich biskupa Aleksandra Kaszkiewicza (1998-2018). 
Pod kierunkiem ks. dr. hab. Mariana Pokrywki, prof. KUL:

Andrei B u r a k: Małżeństwo i rodzina w nauczaniu Kościoła Prawosławnego na Białorusi.

Viktoriia L e v k i v s k a: Rodzina chrześcijańska środowiskiem wychowania do dojrzałej miłości.

Marta H e j d u k: Moralny sens daru z siebie w miłości małżeńskiej w nauczaniu Benedykta XVI.

Pod kierunkiem ks. dr. Jarosława Wojtkuna:

Daniel W i e c h e ć: Treści moralne w nauczaniu papieskim biskupa Edwarda Materskiego.

Pod kierunkiem ks. dr. hab. Tadeusza Zadykowicza, prof. KUL:

Artur C i e k o t: Zasada wyboru mniejszego zła w ocenie wybranych ingerencji w życie i zdrowie człowieka.

\section{Z ŻYCIA INSTYTUTU}

\section{Stan personalny:}

\section{A. Katedra Teologii Moralnej Fundamentalnej i Ekumenicznej}

Kierownik - Ks. dr hab. Marian Pokrywka, prof. KUL

Ks. dr hab. Sławomir Nowosad, prof. KUL

Ks. dr hab. Tadeusz Zadykowicz, prof. KUL

Ks. dr Jarosław Wojtkun, adiunkt

\section{B. Katedra Teologii Moralnej Społecznej}

Kierownik - Ks. prof. dr hab. Jerzy Gocko SDB

O. prof. dr hab. Andrzej Derdziuk OFMCap

Ks. dr hab. Krzysztof Jeżyna, adiunkt

\section{Katedra Bioetyki Teologicznej}

Kierownik - Bp dr hab. Józef Wróbel SCJ, prof. KUL

Ks. dr Krzysztof Smykowski, asystent

Ks. dr Marek Kumór, adiunkt

Pracami Instytutu kierował ks. dr hab. Tadeusz Zadykowicz, prof. KUL. Ks. dr Krzysztof Smykowski pełnił funkcję sekretarza Instytutu, ks. prof. dr hab. Jerzy Gocko - funkcję redaktora tematycznego czasopisma „Roczniki Teologiczne” z. 3: Teologia moralna.

Instytut organizował regularne spotkania wszystkich pracowników ITM, podczas których omawiano aktualne zagadnienia naukowe i organizacyjne. Świadectwem regularności i różnorodności poruszanych zagadnień są protokoły spisywane przez sekretarza ITM, ks. dr. Krzysztofa Smykowskiego. 
Pracownicy Instytutu prowadzili swoje zajęcia dydaktyczne według programu przyjętego przez Radę Wydziału i zatwierdzonego przez Senat Akademicki KUL.

Pracownicy Instytutu prowadzili ponadto wykłady:

A. Derdziuk: Wykłady na temat charyzmatu instytutów życia konsekrowanego; Szkoła Formacji Duchowej Salwatorianów w Trzebini - 5 godz.

Teologia życia zakonnego (wykład); WSD Kapucynów w Lublinie, semestr II 15 godz.; Powołanie do życia konsekrowanego (wykład); Szkoła Formacji Duchowej Salwatorianów we Lwowie; 6-8 maja 2018 - 8 godz.

J. Gocko: Teologia moralna i katolicka nauka społeczna (seminarium magisterskie); WSD Towarzystwa Salezjańskiego w Krakowie; I-II semestr - 30 godz.; Teologia moralna szczegółowa (wykład); WSD Towarzystwa Salezjańskiego w Krakowie; I semestr - 30 godz.; II semestr - 15 godz.

S. Nowosad: Cykl wykładów o tematyce antropologicznej, bioetycznej i kulturowej dla duszpasterzy TChr z USA i Kanady; Pompano Beach, Floryda, USA, 59.02. 2018 -24 godz.

M. Pokrywka: Rzym przez dziurke od klucza (wykład). Uniwersytet Trzeciego Wieku w Siennicy Różanej, 6 października 2017 r. - 2 godz.; Człowiek bładzacy i poraniony. Wykład w ramach Kursu Wyższej Kultury Religijnej zorganizowanego przez Uniwersytet Otwarty KUL, 2 marca 2018 r. - 5 godz.; Człowiek nawracajacy się i pojednany. Wykład w ramach Kursu Wyższej Kultury Religijnej zorganizowanego przez Uniwersytet Otwarty KUL, 9 marca 2018 r. - 5 godz.; Przyjaźń: dar $i$ zadanie (wykład). Uniwersytet Trzeciego Wieku w Siennicy Różanej, 11 marca 2018 - 2 godz.

K. Smykowski: Wprowadzenie w chrześcijaństwo: życie moralne (wykład); Postulat Misyjny Księży Sercanów w Pliszczynie; I semestr - 28 godz.; Wybrane zagadnienia z bioetyki szczegółowej (wykład monograficzny); Wyższe Seminarium Duchowne Diecezji Bydgoskiej; I semestr - 30 godz.; Cztowiek istota „ku mitości”. Wykład w ramach Kursu Wyższej Kultury Religijnej zorganizowanego przez Uniwersytet Otwarty KUL, 23 listopada 2017 - 5 godz.; Człowiek istota cielesna - podstawy bioetyki katolickiej Wykład w ramach Kursu Wyższej Kultury Religijnej zorganizowanego przez Uniwersytet Otwarty KUL, 15 grudnia 2017 - 5 godz.

J. Wojtkun: Teologia moralna ogólna (wykład), Papieski Wydział Teologiczny w Warszawie, Instytut Teologiczny w Radomiu, II semestr - 30 godz.

T. Zadykowicz: Teologia moralna szczegółowa (wykład i ćwiczenia); Archidiecezjalne Wyższe Seminarium Duchowne w Białymstoku, I-II semestr - 5 godz. tyg.

Wszyscy pracownicy samodzielni prowadzili seminaria naukowe. Ks. dr J. Wojtkun prowadził seminarium magisterskie w Wyższym Seminarium Duchownym w Sandomierzu i Radomiu. 
Pracownicy Instytutu: A. Derdziuk, M. Pokrywka, K. Smykowski, J. Wróbel, T. Zadykowicz byli członkami komisji egzaminów licencjackich 4 czerwca 2018 r. Z kolei członkami Wydziałowej Komisji Rekrutacyjnej byli: M. Pokrywka, K. Smykowski, J. Wojtkun, T. Zadykowicz.

Instytut Teologii Moralnej był organizatorem Ogólnopolskiej Konferencji Naukowej pt. „Bł. Honorat Koźmiński” (Lublin, 21.10.2017 r.); Ogólnopolskiej Konferencji Naukowej pt. „Integralność ciała ludzkiego jako powinność moralna i granice jego naruszalności" (Lublin, 6.12.2017 r.) i Ogólnopolskiej Konferencji Naukowej pt. „Doświadczenia na zwierzętach jako przedmiot refleksji interdyscyplinarnej” (Lublin, 25.04.2018).

Pracownicy Instytutu organizowali lub wygłosili referaty na następujących konferencjach naukowych:

A. Derdziuk: Ogólnopolska Konferencja Naukowa pt. „Biotechnologia jutra”, Lublin KUL, 19-20.10.2017. Referat: Etyczny wymiar biotechnologii; Ogólnopolska Konferencja Naukowa pt. „Błogosławiony Honorat Koźmiński. W stulecie śmierci”. Lublin KUL, 1.10.2017. Referat: Architekt; Ogólnopolska Konferencja Naukowa pt. „Karol Wojtyła. Biskup Duszpasterz Profesor”. Wadowice, 22.05.2018. Referat: Kaptaństwo Karola Wojtyty - Jana Pawła II; Kapituła Namiotów Prowincji Zakonu Braci Mniejszych św. Franciszka; Gostyń 5.06.2018. Wykład: Modlitwa i duch pobożności brata mniejszego.

J. Gocko: Sympozjum z cyklu: „Pogranicza. Kaszubskie camino” pt. „Czy możliwy jest dialog międzykulturowy i międzyreligijny we współczesnym świecie? Łeba, 2.09.2017. Referat: Chrześcijańska wizja dialogu międzykulturowego i międzyreligijnego; Międzynarodowa Konferencja Interdyscyplinarna pt. „Wiara i ekologia. Chrześcijańska odpowiedź na «Troskę o nasz wspólny dom»". Olsztyn, 21.11.2017. Referat: Kryzys ekologiczny a pytanie o sprawiedliwość społeczna z perspektywy polskiej $i$ międzynarodowej; XI Zjazd Towarzystwa Naukowego Franciszka Salezego. Stoczek Klasztorny, 18-19.05.2018. Komunikat.

S. Nowosad: „Executive Program for Catholic Leadership”. University of Notre Dame, USA, 8-15.07.2017. Udział w dyskusjach; „Osoba ludzka - rzeczywistość czy użyteczna metafora?". Towarzystwo Teologów Dogmatyków. Lublin, 19.09.2017. Wprowadzenie; „The Church in Poland and John Paul II, Lublin, 16-20.10.2017, referat pt. Church-State Relations in Poland; „Człowiek i teologia we współczesnej kulturze”. Instytut Teologiczny, Lwów, 21.10.2017. Referat: Trwa spor o człowieka - od antropologicznego błędu do antropologicznej rewolucji; ,The Dead Sea Scrolls 70 Years Later". Lublin, 24-25.10.2017. Wprowadzenie do konferencji: The Word of God Still Relevant; „Marcin Luter pięć wieków później - 500-lecie reformacji”. Komitet Nauk Teologicznych PAN, Warszawa, 16.11.2017. Udział w dyskusji; „25lecie Fundacji Jacka Krawczyka”. Lublin, 22.11.2017. Wprowadzenie do konferencji: Ocalić od zapomnienia tych, którzy tworzyli historię WT i KUL; „100-lecie teologii fundamentalnej na KUL”. Lublin, 4.12.2017. Wprowadzenie i uwagi wstępne: Teolo- 
gia fundamentalna w historii WT KUL; „Integralność ludzkiego ciała jako powinność moralna i granice jej naruszalności". Lublin, 6.12.2017. Uwagi wprowadzające: Nieodzowność bioetyki w teologii moralnej; „Educational Programme: John Paul II in His Polish Context". Lublin, 2-27.01.2018. Konsultant merytoryczny, udział w dyskusjach, referat: St. John Paul II's Faith; „Sesja pt. 100-lecie KUL”. Watykan, Papieska Akademia Nauk, 26.04.2018; Konferencja pt. „KUL uniwersytetem niepodległej Polski”. Senat RP, Warszawa, 8.05.2018; „Ogólnopolska Pielgrzymka Akademicka”. Częstochowa, 12.05.2018. Wykład do rektorów i profesorów wyższych uczelni polskich: Człowiek w centrum każdego uniwersytetu; ,Teoria i praktyka muzyki kościelnej. Tradycja i współczesność". Lublin, 16.05.2018. Uwagi wprowadzające: Muzyka kościelna w kontekście teologii; „Catholic Universities Partnership: The Role of the Catholic University in Time of the Tensions of Populism and Nationalism". Lwów, UCU, 17-19.05.2018. Referat: Resisiting Temptations; „General Assembly of the European Federation of Catholic Universities: Catholic Education and Social Sciences and Humanities". Lublin, 24-26.05.2018. Prowadzenie sesji wprowadzającej, udział w dyskusjach; „Kościół wobec pluralizmu w życiu społecznym - dialog czy konflikt?”. Stowarzyszenie Teologów Moralistów, Toruń, 11-12.06.2018. Współorganizator, udział w dyskusjach.

M. Pokrywka: Ogólnopolska Konferencja Naukowa pt. „Doświadczenia na zwierzętach jako przedmiot refleksji interdyscyplinarnej”. Lublin, 25.04.2018. Przewodniczenie sesji; Międzynarodowa Konferencja Naukowa pt. „Kościół wobec pluralizmu w życiu społecznym. Dialog czy konflikt?”. Toruń, 10-12.06.2018. Przewodniczenie sesji.

K. Smykowski: Ogólnopolska Konferencja Naukowa pt. „Integralność ciała ludzkiego jako powinność moralna i granice jego naruszalności”. Lublin, 6.12.2017. Współorganizator, referat: Integralność ciała ludzkiego z perspektywy teologicznomoralnej - analiza dwóch przypadków; Ogólnopolska Konferencja Naukowa pt. „Doświadczenia na zwierzętach jako przedmiot refleksji interdyscyplinarnej”. Lublin, 25.04.2018. Główny organizator, referat: Doświadczenia na zwierzętach w nauczaniu Kościoła $i$ w refleksji teologicznomoralnej; Konferencja Naukowo-Szkoleniowa Oddziału Śląskiego Polskiego Towarzystwa Anestezjologii i Intensywnej Terapii. Wisła, 8-10 czerwca 2018. Referat: Terapia daremna z perspektywy bioetyki katolickiej; X Konferencja Adeptów Fizjologii pt. „Homeostaza - mikrobiom - ksenobiotyki”. Lublin, 13-14.09.2018. Referat: Teologicznomoralne aspekty prowadzenia doświadczeń na zwierzętach.

J. Wojtkun: X Ogólnopolska Konferencja Wolontariatu hospicyjnego pod hasłem „Idźcie i głoście w posłudze hospicyjnej”, Radom, 7.10.2017. Referat: Postuga hospicyjna miejscem głoszenia Ewangelii zycia; Konferencja Naukowo-Szkoleniowa „Podaruj cząstkę siebie”. Powiatowa Stacja Sanitarno-Epidemiologiczna. Radom, 30.11. 2017. Referat: Transplantacje narzadów - refleksja etyczna; Ogólnopolska Konferencja Naukowa pt. „Integralność ciała ludzkiego jako powinność moralna i granice jego naruszalności”. Lublin, 6.12.2017. Prowadzenie drugiej sesji; Konferencja Naukowa pt. „Dojrzewanie - pułapką uzależnień”. Wyższa Szkoła Handlowa. Radom, 14.12. 2017. Referat: Wspótczesne formy uzależnień. Chrześcijański Kongres Społeczny 
„Suwerenność - Chrześcijaństwo - Europa”. Radom, 16.12.2017. Udział w panelu: Polska głosem chrześcijańskiej Europy; Konferencja Naukowa pod hasłem „Transplantacja darem życia - jestem na TAK”, Radomski Szpital Specjalistyczny, Radom. 29.01.2018. Referat: Ofiarowanie narzadów wyrazem miłości większej.

J. Wróbel: Ogólnopolska Konferencja Naukowa pt. „Integralność ciała ludzkiego jako powinność moralna i granice jego naruszalności”. Lublin, 6.12.2017. Organizator, podsumowanie; Międzynarodowa Konferencja Naukowa pt. „Otoczmy troską życie”. Białystok, 18.11.2017. Referat: Preselekcja ptci dziecka z perspektywy bioetyki katolickiej; Konferencja zorganizowana przez Dolnośląsko-Opolską Szkołę Ordynatorów Oddziałów Anestezjologii i Intensywnej Terapii oraz przez Polskie Towarzystwo Anestezjologii i Intensywnej Terapii pt. „Terapia daremna”. Kamień Śląski, 12.04.2018. Referat: Terapia daremna z perspektywy bioetyki katolickiej.

T. Zadykowicz: Bt. Honorat Koźmiński. Ogólnopolskie Sympozjum Naukowe (KUL Lublin, 21.10.2017). Organizatorzy: Prowincja Warszawska Braci Mniejszych Kapucynów, Instytut Teologii Moralnej KUL; 25-lecie Fundacji im. Jacka Krawczyka (KUL Lublin, 22.11.2017). Organizatorzy: Fundacja im. Jacka Krawczyka, Wydział Teologii KUL; Integralność ludzkiego ciała jako powinność etyczna i granice jego naruszalności (KUL Lublin, 6.12.2017). Organizator: Instytut Teologii Moralnej KUL, Organizacja i przewodniczenie sesji; „Po co teologia?” 50. Tydzień Eklezjologiczny (KUL Lublin, 16-20.04.2018), Przewodniczenie sesji VIII (Teologia moralna) 19.04.2018; Ogólnopolska Konferencja Naukowa „Doświadczenia na zwierzętach jako przedmiot refleksji interdyscyplinarnej”. Lublin, 25.04.2018.

Pracownicy Instytutu pełnili następujące funkcje pozaetatowe na Uczelni:

A. Derdziuk: członek korespondent Towarzystwa Naukowego KUL; członek Rady Naukowej Instytutu Jana Pawła II KUL.

J. Gocko: zastępca redaktora naczelnego czasopisma „Roczniki Teologiczne”; redaktor tematyczny i sekretarz czasopisma „Roczniki Teologiczne” z. 3: Teologia moralna; członek korespondent Towarzystwa Naukowego KUL; egzaminator z teologii moralnej w ramach uzupełnień studiów teologicznych.

K. Jeżyna: członek korespondent Towarzystwa Naukowego KUL; egzaminator z teologii moralnej przed obroną pracy magisterskiej.

S. Nowosad: dziekan Wydziału Teologii KUL; redaktor naczelny „Roczników Teologicznych"; członek Towarzystwa Naukowego KUL; członek Kapituły ds. Odznaczeń i Medali KUL; członek Komisji ds. Nauki KUL; członek ds. Opracowania Nowego Statutu KUL; członek Komisji Odwoławczej ds. Oceny Pracowników Naukowych; członek Rady Naukowej MISHiS KUL; członek Rady Naukowej CTW KUL; członek Rady Naukowej Instytutu Jana Pawła II KUL; członek Rady Programowej Uniwersytetu Otwartego KUL; członek zespołu recenzentów kwartalnika „Ethos”; członek zespołu recenzentów czasopisma „Roczniki Kulturoznawcze”.

M. Pokrywka: członek współpracownik Towarzystwa Naukowego KUL.

K. Smykowski: sekretarz Instytutu Teologii Moralnej; członek (z wyboru) Rady Wydziału Teologii KUL; pełnomocnik ds. etyki badań naukowych z udziałem ludzi 
z ramienia Wydziału Teologii KUL; koordynator XV Lubelskiego Festiwalu Nauki z ramienia Wydziału Teologii KUL;

J. Wróbel: członek korespondent Towarzystwa Naukowego KUL;

T. Zadykowicz: dyrektor Instytutu Teologii Moralnej; członek współpracownik Towarzystwa Naukowego KUL; członek Wydziałowej Komisji ds. Jakości Kształcenia; członek Wydziałowej Komisji Dyscyplinarnej; członek Komisji Dyscyplinarnej ds. Pracowników; członek Komisji ds. Promocji Wydziału Teologii KUL; członek Wydziałowej Komisji Kwalifikacyjnej do merytorycznego badania wniosków o przyznanie stypendiów doktoranckich na stacjonarnych studiach doktoranckich KUL; członek Wydziałowej Komisji Kwalifikacyjnej do merytorycznego badania wniosków o przyznanie zwiększenia stypendium doktoranckiego z dotacji podmiotowej na dofinansowanie zadań projakościowych; członek Komisji Konkursowej ds. przyznawania stypendiów naukowych dla uczestników studiów doktoranckich i młodszych pracowników naukowych.

Poza Uczelnią pracownicy Instytutu pełnili następujące funkcje:

A. Derdziuk: członek Polskiej Komisji Akredytacyjnej; przewodniczący VI Wydziału Nauk Teologicznych Lubelskiego Towarzystwa Naukowego; członek zwyczajny Stowarzyszenia Teologów Moralistów; egzaminator egzaminów jurysdykcyjnych dla młodych kapłanów w Prowincji Warszawskiej w zakresie teologii moralnej; członek Rady Naukowej czasopisma „Roczniki Teologiczne” z. 2: Teologia dogmatyczna; członek Rady Naukowej czasopisma „Roczniki Teologiczne” z. 3: Teologia moralna; członek Rady Naukowej czasopisma „Roczniki Teologiczne” z. 5: Teologia duchowości; członek zespołu recenzentów czasopisma „Collectanea Franciscana” Rzym; członek zespołu recenzentów czasopisma „Polonia Sacra”; członek zespołu recenzentów czasopisma „Teologia i Moralność”; członek zespołu recenzentów czasopisma „Ethos”.

J. Gocko: redaktor naczelny czasopisma „Seminare”; członek Zarządu Towarzystwa Naukowego Franciszka Salezego; członek Stowarzyszenia Teologów Moralistów; członek Lubelskiego Towarzystwa Naukowego; członek Sekcji Wykładowców Katolickiej Nauki Społecznej; członek komisji ds. studiów Inspektorii św. Jacka Towarzystwa Salezjańskiego w Krakowie; członek zespołu recenzentów czasopisma „Annales. Etyka w życiu gospodarczym”; członek zespołu recenzentów czasopisma „Forum Teologiczne. Rocznik Naukowy Wydziału Teologii Uniwersytetu Warmińsko-Mazurskiego w Olsztynie”; członek zespołu recenzentów czasopisma „Studia Nauk Teologicznych Polskiej Akademii Nauk”; członek zespołu recenzentów czasopisma „Studia Historyczno-Teologiczne Śląska Opolskiego".

K. Jeżyna: członek Lubelskiego Towarzystwa Naukowego; członek Towarzystwa Naukowego Franciszka Salezego; członek zwyczajny Stowarzyszenia Teologów Moralistów; członek Komisji Bioetycznej przy Lubelskiej Izbie Lekarskiej.

M. Kumór: dyrektor Wydziału Duszpasterstwa Kurii Diecezjalnej w Sandomierzu; koordynator Dzieła Nowego Tysiąclecia; członek zespołu cenzorów w Diecezji Sandomierskiej; członek zwyczajny Stowarzyszenia Teologów Moralistów. 
S. Nowosad: członek Komitetu Naukowego AVEPRO, Watykan; członek International Institute for Hermeneutics, Toronto, Kanada; członek Catholic Universities Partnership, University of Notre Dame, USA; członek Komitetu Nauk Teologicznych PAN; członek rzeczywisty Lubelskiego Towarzystwa Naukowego; członek Rady Naukowej Konferencji Episkopatu Polski; wiceprzewodniczący Zarządu Stowarzyszenia Teologów Moralistów; członek zespołu recenzentów Narodowego Centrum Nauki; członek Komitetu Redakcyjnego czasopisma „Studia Nauk Teologicznych PAN”; członek Rady Naukowej czasopisma „Teologia i Moralność”; członek zespołu recenzentów czasopisma „Teologia i Moralność”; członek zespołu recenzentów czasopisma „Studia Theologica Varsaviensia”; członek zespołu recenzentów czasopisma „Seminare”; członek zespołu recenzentów czasopisma „Analecta Cracoviensia”; przewodniczący Diecezjalnej Komisji ds. Wyższego Seminarium Duchownego (Diecezja ZamojskoLubaczowska); członek diecezjalnej Komisji Teologicznej Procesu Beatyfikacyjnego ks. Błażeja Nowosada (Diecezja Zamojsko-Lubaczowska).

M. Pokrywka: członek zwyczajny Stowarzyszenia Teologów Moralistów Polskich; członek Europejskiego Stowarzyszenia Teologów Katolickich; członek korespondent Lubelskiego Towarzystwa Naukowego; członek zwyczajny Towarzystwa Naukowego Franciszka Salezego; członek Komisji Teologii Oddziału Polskiej Akademii Nauk w Lublinie; członek Polskiego Towarzystwa Geograficznego. Oddział w Lublinie.

K. Smykowski: członek Zespołu Ekspertów Konferencji Episkopatu Polski ds. Bioetycznych; członek Lokalnej Komisji Etycznej do Spraw Doświadczeń na Zwierzętach w Lublinie; członek zwyczajny Stowarzyszenia Teologów Moralistów; członek Europejskiego Stowarzyszenia Teologów Katolickich; członek Stowarzyszenia „Bioethicists in Central Europe” (BCE); członek Rady Naukowej czasopisma „Studia Bydgoskie".

J. Wojtkun: rektor Wyższego Seminarium Duchownego w Radomiu; członek zwyczajny Stowarzyszenia Teologów Moralistów; przewodniczący Synodalnej Komisji Nauki i Wychowania Katolickiego; wiceprzewodniczący Radomskiego Oddziału Polskiego Towarzystwa Teologicznego; członek Komitetu Naukowego Serii Wydawniczej Theologia Radomiensis; członek zespołu redakcyjnego kwartalnika „Zeszyty Formacji Katechetów"; członek zespołu recenzentów publikacji pod względem zgodności z nauką Kościoła w zakresie wiary i moralności przy Kurii Diecezji Radomskiej.

J. Wróbel: biskup Pomocniczy Archidiecezji Lubelskiej; członek Stowarzyszenia Teologów Moralistów; członek Rady Naukowej czasopisma „Teologia i Moralność”; członek Rady Naukowej czasopisma „Horyzonty Wychowania”; członek Rady Naukowej czasopisma „Bioetyczne Zeszyty Pediatrii”; członek Rady Naukowej czasopisma „Sympozjum”; przewodniczący Zespołu Ekspertów Konferencji Episkopatu Polski ds. Bioetycznych; członek Stowarzyszenia „Bioethicists in Central Europe” (BCE); członek Stowarzyszenia Teologów Moralistów „Forum Moraltheologie Mitteleuropa”; członek Towarzystwa Naukowego Franciszka Salezego; przewodniczący Kapituły Wyróżnienia „Książka Teologicznomoralna Roku” przyznawanego przez Stowarzyszenie Teologów Moralistów. 
T. Zadykowicz: członek korespondent Lubelskiego Towarzystwa Naukowego; członek Europejskiego Stowarzyszenia Teologów Katolickich; członek zwyczajny Stowarzyszenia Teologów Moralistów; przewodniczący Komisji Rewizyjnej Stowarzyszenia Teologów Moralistów; członek Towarzystwa Naukowego Franciszka Salezego; członek zespołu recenzentów czasopisma „Studia Theologica Varsaviensia”; członek zespołu recenzentów czasopisma „Teologia i Moralność”; członek zespołu recenzentów czasopisma „Scripturae lumen”; członek zespołu recenzentów czasopisma „Studia Nauk Teologicznych Polskiej Akademii Nauk"; członek zespołu recenzentów czasopisma „Studia Sandomierskie. Teologia - Filozofia - Historia”.

Pracownicy Instytutu wydali następujące monografie naukowe: M. Pokrywka: Człowiek i środowisko. Moralny wymiar ekologii. Lublin: Wydawnictwo Diecezjalne i Drukarnia w Sandomierzu 2017; K. Smykowski: Eksperymenty medyczne z wykorzystaniem zwierzat. Lublin: Wydawnictwo KUL 2017 oraz następujące prace zbiorowe: Boży człowiek w stużbie ludziom. Bt. Honorat Koźmiński. Red. A. Derdziuk, G. Filipiuk. Lublin: Wydawnictwo Diecezjalne i Drukarnia w Sandomierzu 2018; Drogami świętości Jacka Krawczyka. Red. A. Derdziuk, A. Zadroga. Lublin: Wydawnictwo Diecezjalne i Drukarnia w Sandomierzu 2018; Vigo A. Demant. Not One World but Two: A Miscellany of Preachments. Red. S. Nowosad. Lublin: TN KUL 2017; 100 lat teologii na KUL. Red. S. Nowosad, J. Mastej. Lublin: Wydawnictwo KUL 2018.

Oprócz tego opublikowali 40 artykułów naukowych oraz 15 recenzji wydawniczych i sprawozdań, a także oddali to druku 38 publikacji.

Pracownicy Instytutu przygotowali 2 recenzje doktorskie: S. Nowosad - 2 (KUL, UŚ); 27 recenzji magisterskich: A. Derdziuk - 5; J. Gocko - 3; S. Nowosad - 4; M. Pokrywka - 7; K. Smykowski - 3; J. Wojtkun - 2; T. Zadykowicz - 4 oraz 15 recenzji wydawniczych: A. Derdziuk - 4; J. Gocko - 2; M. Pokrywka - 1; S. Nowosad - 1; T. Zadykowicz - 7.

Dnia 4 czerwca odbyły się egzaminy licencjackie z teologii moralnej dla studentów II roku kursu wyższego. Egzaminy zdali i otrzymali tytuł licencjata: ks. Józef Bożek, ks. Wojciech Komosa, ks. Karol Waga, ks. Tomasz Wasilewski i ks. Adam Woch.

Pracownicy Instytutu przygotowali materiały do opublikowania w „Rocznikach Teologicznych" z. 3: Teologia moralna za rok 2019. 